\title{
The Main Structural Patterns of Verbal Phraseological Units in English and Albanian
}

\author{
Rovena Vora, Ph.D., \\ Esmeralda Subashi, Ph.D. \\ University of Tirana, Faculty of Foreign Languages \\ English language Department \\ E-mail: rovena.vora@gmail.com
}

\section{Doi:10.5901/mjss.2013.v4n13p637}

\begin{abstract}
This paper introduces a comparative approach to the structural patterns of verbal phraseological units in English and Albanian. The structural criterion brings forth pronounced distinctive features characterising phraseological units and especially contrasting them to free word-groups. In the same way as we speak of word patterns, the structure of phraseological units is also based on certain patterns. In this paper we are going to focus on verbal phraseological units which compared to free word-groups have structural stability, semantic unity and figurativeness. Both languages, English and Albanian are very rich in such phrases and share some similarities. Structural invariability is an essential feature of phraseological units, though, as we shall see, some of them possess it to a lesser degree than others. Structural invariability of phraseological units finds expression in a number of restrictions. The aim of this study is to find out the main restrictions regarding the structure of verbal phraseological units and to give the main structural patterns in both languages. Their structure is contrasted and compared by use of examples in English and Albanian as well.
\end{abstract}

Keywords: verb, phraseological unit, idiom, idiomatic, structure, pattern.

\section{Introduction}

Phraseological units, or idioms, represent what can probably be described as the most picturesque, colourful and expressive part of the language's vocabulary. Generally, phraseological units are defined as units made up of at least two words, as unique combinations of words not created according to a certain pattern and no other combinations can be created accordingly. Combinatory abilities of phraseological units are different from the combinatory abilities of regular language. This means that elements of idiomatic units can combine only with particular elements. Phraseological units are expressions which have been used over time so frequently that they lose their special features and which many speakers are familiar with. Furthermore, they are characterised by paradigmatic fixity, as elements part of phraseological units are not substitutable in the same place in a particular context.

Word-groups known as phraseological units or idioms are characterised by a double sense: the current meanings of constituent words build up a certain picture, but the actual meaning of the whole unit has little or nothing to do with that picture, in itself creating an entirely new image. The term "idiom" is mostly applied to phraseological units with completely transferred meanings, that is, to the ones in which the meaning of the whole unit does not correspond to the current meanings of the components. There are many scholars who regard idioms as the essence of phraseology and the major focus of interest in phraseology research. The structural criterion also brings forth pronounced distinctive features characterising phraseological units and contrasting them to free word-groups. Structural invariability is an essential feature of phraseological units, though some of them possess it to a lesser degree than others. (Ginzburg, R.S./ Khiedel, S.S./Knyazeva, Sankin, A.A.,1999)

Structural invariability of phraseological units finds expression in a number of restrictions. First of all, restriction in substitution. As a rule, no word can be substituted for any meaningful component of a phraseological unit without destroying its sense. At the same time, in free word-groups substitution does not present any dangers and does not lead to any serious consequences. The second type of restriction is the restriction in introducing any additional components into the structure of a phraseological unit. In a free word-group such changes can be made without affecting the general meaning of the utterance. In the phraseological unit to carry coals to Newcastle no additional components can be introduced. Nor can one speak about somebody having his heart in his "brown" boots. (Ginzburg, R.S./ Khiedel, S.S./Knyazeva, Sankin, A.A.,1999) 
In fiction, such variations of idioms created for stylistic purposes are not a rare thing. In oral speech, phraseological units mostly preserve their traditional structures and resist the introduction of additional components. The third type of structural restrictions in phraseological units is grammatical invariability. A typical mistake with students of English is to use the plural form of fault in the phraseological unit to find fault with somebody (e. g. The teacher always found faults with the boy). Though the plural form in this context is logically well-founded, it is a mistake in terms of the grammatical invariability of phraseological units. A similar typical mistake often occurs in the unit from head to foot (From head to foot he was immaculately dressed). Students are apt to use the plural form of foot in this phrase, thus, erring once more against the rigidity of structure which is so characteristic of phraseological units. Yet again, as in the case of restriction in introducing additional components, there are exceptions to the rule, and these are probably even more numerous. One can build a castle in the air, but also castles. (Ginzburg, R.S./ Khiedel, S.S./Knyazeva, Sankin, A.A.,1999)

It is generally known that word-groups may be generally described through the pattern of arrangement of the constituent members. The term 'syntactic structure' (formula) implies the description of the order and arrangement of components as parts of speech. These formulas can be used to describe all the possible structures of English wordgroups. We can say, e.g., that the verbal groups comprise the following structural formulas: $V+N$ (to build houses), $V+p r p+N$ (to rely on somebody), $V+N+p r p+N$ (to hold something against somebody), $V+N+V$ (inf.) (to make somebody work), $V+V$ (inf.) (to get to know), and so on. The structure of word-groups may be also described in relation to the headword, e.g. the structure of the same verbal groups (to build houses, to rely on somebody) is represented as to build $+\mathrm{N}$, to rely + on $+N$. In this case it is usual to speak of the patterns of word-groups but not of formulas. The term 'pattern' implies that we are speaking of the structure of the word-group in which a given word is used as its head.

The interdependence of the pattern and meaning of head-words can be easily perceived by comparing wordgroups of different patterns in which the same head-word is used. Regarding English and Albanian language, verbal phraseological units with a dependent structure occupy a prominent place. It is the first component in these phraseological units which conveys the meaning of the whole phrase. While the other components give the phrase semantic exactness. A characteristic feature of the English verbal phraseological units is nowadays the use of monosyllabic verbs which denote different actions such as be, get, look, put etc. In addition, some verbal phraseological units have constant dependence of the elements. In most cases, the second constituent may be the name of animal real actions or imagined ones based upon the real relations among men, as in: die like a dog/fight like a lion.

.The second component may be a thing, or another type: be like a gas - meter/have a head like a sieve. Other verbal phraseological units are never used to denote man's actions or state, as in: spread like wildfire/spring up like mushrooms. The construction of the components with constant variants is extended. It is the word "like" which enlarges its scope of variants.

- verbs may be reciprocal, as in: blow like a grampus/puff like a grampus

- nouns may be reciprocal, as in: live like a lord/live like a prince; work like a horse/a slave

These similes are used for man's actions or to describe one's state. The number of verbs in verbal phraseological units in English which have got more than one component with constant dependency of elements is greater than in the Albanian language, as in stick to somebody like a leech/stick to somebody like wax or treat somebody like a lord/like dirt/like a dog. All these expressions are used to describe man's actions or state. What they have in common is their structure with "like" but the substituting elements are not synonyms. Yet, this type of verbal phraseological units can be employed even for expressions like fit somebody like a glove.

Having considered only such verbal phraseological units the second component of which consists of only one word, but there are still other phrases having even two words as the second constituent. We can provide examples both in English and in Albanian: agree like cats and dogs, take to something like a duck to water and in Albanian: u bë si pulë e lagur, ia bëri kurrizin më të butë se barkun.

In other verbal phraseological units, the interdependence of elements is only temporary, as in live by one's wits. The word - groups of this type function as verbs in a sentence and as such they have some verbal characteristics. One of them is that they denote objective relations. Their structure, being very complicated, can start with simplest pattern: verb + noun as in eat crow or raise Cain - up to mixed types with various elements in between. The verb may be transitive and the nouns may appear with/without the definite article.

There are certain cases, it is true, where the vulgar Saxon word is refined, and the refined Latin vulgar, in poetry as in Sweat and persiration; but there are vastly more in which Latin bears the bell. (James Main Dixson, English idioms, 24) 
Në fillim ai s'i dha rëndësi kësaj çështjeje. E dinte që kishte të bënte me një grua konservatore. Po, me kohë, filloi të vriste mendjen. Dhe, kur vendosi se do të ishte më mirë, për çdo rast, të mos shihej më në shtëpinë e tyre, ndjeu përbrenda një lloj brenge... "Këto s'janë shenja të mira, mor çunak", mendoi me vete. (Shefqet Musaraj, Para agimit, 34)

In English language, the indefinite article is also used:

The uneasiness of the Forsyte family has been justified by the simple mention of the hat. How impossible and wrong would it have been for any family, with the regard for appearances which should ever characterise the great upper middle-class, to feel otherwise than uneasy. The author of the uneasiness stood talking to June by the further door; his curly hair had a rumpled appearance as though he found what was going on around him unusual. He had an air, too, of having a joke all to himself. (John Galsworthy, The Forsyte Saga, 7)

In verbal phraseological units in Albanian, the verb may be followed by a noun, which in contrast to English is not preceded by an article.

Heshtje. Nga jashtë u dëgjua një këngë: këndonte peshkatari që kish mbaruar së shkarkuari peshkun. Ata të dy mbajtën vesh dhe e dëgjuan gjer në fund. Si u shua kënga e peshkatarit, u dëgjua një cicërimë cëri që endej nëpër oborr dhe çukiste me sqep fijet e barit midis rrasave. (Mitrush Kuteli, Vepra letrare 3, 100)

A transitive verb can be followed by a plural noun:

"Do you know, there appears to me to be really immense merit in that work?" and, in short, that people of condition had absolutely taken pains to bring him into fashion. (Charles Dickens, Little Dorrit, 251)

Two plural nouns can be used in the structure of verbal phraseological units after a transitive verb $(\mathrm{V}+\mathrm{N}+\mathrm{N})$ :

They didn't guess what was going to happen, of course; still, they had their suspicions of the Wild Wood animals. Now I come to the most painful and tragic part of my story. One dark night - it was a very dark night, and blowing hard, too, and raining simply cats and dogs - a band of weasels, armed to the teeth, crept silently up the carriage-drive to the front entrance. (Kenneth Grahame, The wind in the willows, 254)

Ju keni të drejt, moj shoqeni, po, gjersa ne vetë nuk e kemi mbledhur mendjen t'i shtrohemi bujqësis, pa menduar orë e çast si e qysh të largohemi nga fshati, me anë martesash në qytet s'kemi sy e faqe të kritikojmë qytetarkat si për shembull gruan e kryetarit, që nuk duan të vijnë në fshat. (Jakov Xoxa, Juga e bardhë, Vol. II, 30)

A pronominal form may be present in the dative case in Albanian referring to a direct or an indirect object which is not part of the idiomatic expression. The noun which is a component of the idiomatic expression may be singular or plural:

Po s'mbajti dot verën, num mban dot as ngjalën e dhjamur qillonë të gjolit të Naforës, o myzeqar!... - tha Pavlloja. Ngjala nuk do dhalla... Ha ngjala e pi dhalla, si në Myzeqe, të fryhet barku dhe të bën llëng-llëng, si matarja e qumështit në kurrizin e labit që shet bulmet nëpër Naforë. Gjersa na ị paska vënë syrin në karnavale një vajze të vetme, pa motër e vëlla, ai duhet të hyjë dhëndërr brenda e të bëhet naforiot, se nuk ia jep njeri nuse... (Jakov Xoxa, Lulja e kripës së egër, 211)

Gurija priste me tmer e krupë se ç'do të ndodhte më tej. Ah, sikur të kish një pus aty pranë, një greminë, që të hidhej, të vdiste... Vetëm të ndodhej sa më larg këtij divani të butë, larg Xheladin Beut të ndezur, të lemerishëm, që e shtrëngonte, gufonte, kafshonte. Mirëpo ndërkaq beut i qe shuar zjarri i ndezur një çast më parë në damarët e fryrë. $\underline{J u}$ prenë këmbët, u zverdh, u ngrys dhe e largoi vetë, duke e kqyrur me ca sy të skuqur, të kërcyer. (Mitrush Kuteli, Tregime të zgjedhura, 147)

Some other common patterns in English are:

- verb + adjective + noun eat humble pie

- verb + definite article + noun in genitive grind the faces of the poor

- verb+ pronoun (indefinite possessive) + noun pull somebody's leg 
- verb $+a+$ adjective + noun + noun in genitive

show a clean pair of heels

- verb + one's + own + noun

have one's own way

- a whole sentence as in:

kill the goose that lays (laid) the golden eggs.

- give + somebody + noun

give somebody the cold shoulder

- verb in the infinitive

have other fish to fry

In many cases they are used only in the negative form, as in: not to lift a hand. The negative particle not may pertain to the second element as well: see no farther than one's nose. In Albanian, the negative particle nuk just as the English one not is often used:

\author{
nuk shtihet në dorë \\ nuk e prishi gjakun \\ nuk çan kokën \\ nuk shkel në dërrasë të kalbur
}

But in the English group of verbal phraseological units not is part and parcel of the word group. Whereas in Albanian nuk may or may not be used as the sentence may be in negative or in the affirmative, as in kot e prishi gjakun ai or s'e prish gjakun kollaj Shaqoja jo!

Other verbal phraseological units have substituting variants, especially variants of the verbs, as in: accept something at its fare value or take something at its fare value. Many examples could show the fact the verbs have got so many synonyms as their counterparts, like - achieve one's end - where the verb achieve can be replaced by 'attain'/'gain'/'secure' one's end:

"I must tell you that if you use such methods you'll never gain your ends".

Various prepositions are part and parcel of different structures in the verbal phraseological units. The most common patterns are:

- verb + preposition + noun:

a light on the lure

appear before the footlights

appeal to the country

- verb + preposition + one's + object:

arrive at one's finger ends

attend upon somebody's leisure

beam in one's eye

The same phraseological unit may take two different prepositions having no change in the meaning, as in: anchor one's hope in - anchor one's hope on. The position of the preposition is not stable within one and the same expression in English:

see on which side the bread is buttered see which side the bread is buttered on see which side the bread is buttered

The following are the most common and frequent prepositions which enter into collocation with various phraseological structures:

about: have a millstone about above: Keep one's head above water according to: cut one's coat according to one's cloth against: knock one's head against a brick at: take the tide at the flood 
before: put the cart before the horse

by: take the bull by the horns

from under: cut the ground from under somebody's feet

in: take one's life in one's hands

into: knock somebody into the middle of next week

off: carry somebody off his feet

on: hit the nail on the head

out of: take the words out of somebody's mouth

over: throw one's cap over the wind mill

to: add fuel to the fire

under: think under fire

up: have something up one's sleeve

upon: cast one's bread upon the waters

with: take a hard line with someone

without: make an omelette without breaking eggs

The Albanian language does not lag behind in this respect, too.
në: e la në baltë
nëpër : merr nëpër gojë
me : e bëri me shëndet
nga: heq nga mendja
ndër: i ra ndër këmbë

The verbal phraseological units expressing adverbial relations are few in English, fewer than in Albanian:

\author{
be up one's neck in something \\ dance on a volcano \\ drag in by the head and shoulders \\ fall between two stools.
}

In Albanian, vij vërdallë, vij rrotull etc:

Ja, këto gjëra i vinin vërdallë në kokë së bijës së Nures, atje në mezhdën që ndante arat e Gjatollinjve nga arat e Gjonomadhëve. Vrugoi ballin, rrahu ta mbushë me zhubra, po më kot: sepse zhubrat e sjellin vjetet e jo dëshirat. (Mitrush Kuteli, Tregime të zgjedhura, 74)

Kur u shkëputën ishin si të dehur: u vinte rrotull gijthë Mali i Thatë me majat e blerimet e tij, gjithë liqeri i Lyhnidës me kaltërsinë e tij. U ulën e ndenjën pranë në lëkurën e ariut, që aty më parë kish qenë shalë kali dhe tani ish bërë shtojcë. (Mitrush Kuteli, Vepra letrare 3, 18)

They often take a direct object as in:

Bota, e zbardhëllyer nga shënditjet e faqes së kënetës, i erdhi rreth e rrotull, si rrotë mulliri, mbytur në atë pahun e imtë e të artë të miellit. Mblodhi fuqitë që $i$ kishin mbetur, i mbërtheu me dhëmbë në nofullat e shtrënguara, që të mos $i$ shkonin huq, dhe, duke i dhënë vërtik shpatullës, e vërtiti beun, në kënetë dhe vetë, i lehtësuar në shpinë e në zemër ua mbathi këmbëve. (Jakov Xoxa, Lumi i vdekur, Vol. II, 84-85)

The verb within the structure of the phraseological unit may be in the passive:

Dëgjo, bujer, - $i$ tha, - kontratat i ke zotrote, nuk i kemi ne. Zotrote ke fitimet, pra zotrote paguaj gjobat. Me ne s'ke kontrata. Po të mos kesh leverdi, na dëbon menjëherë, siç bëre atë motin e krizës. Ty s'të bëhet vonë për ne. As mua. (Mitrush Kuteli, Vepra letrare 3, 387)

Po përse atëhere ti, shoku Kito, partizan i vjetër, që je gati të ngrihesh e të shkosh në ndihmë të malësisë, kundërshton të bashkohesh me kooperativën fainje...? Kitoja mbeti gojëhapur. Po të kishte qenë minderi i mbushur jo me pambuk, por me lëpushka, si dikur, do të ishte dëgjuar trazimi i tij. (Jakov Xoxa, Juga e bardhë, Vol. I, 479)

It is typical of the verbal phraseological units in English to replace the noun in the genitive with the 'of phrase', like: 
bang something into somebody's head - bang something into the head of one.

In some verbal phraseological units there also exists the possibility of the verb substitution as a result of synonymy. The same happens with the adjectives. In the following examples, the noun is replaced by other nouns which are not synonymous, yet they denote all one and the same notion:

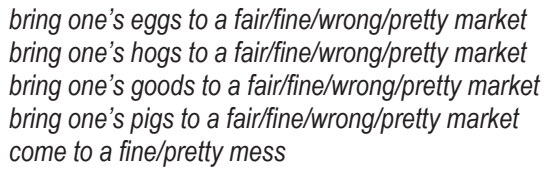

Moreover, the verbal phraseological units have found their way in the everyday speech; for instance, the verb 'care' in 'not to care a fig/a rap/ a snap' is always used in its negative form. An adjective may often serve as an attribute to the nouns - not to care a damn rap or not to care a damn rap to it. The numeral, too, can be used in colloquial phrases, as well as in Standard English:

care two hoots/pins/straws

carry two faces under one's hood

\section{Concluding Remarks}

Word-groups and phraseological units possess not only the lexical meaning, but also the meaning conveyed mainly by the pattern of arrangement of their constituents. A certain parallel can be drawn between the meaning conveyed by the arrangement of morphemes in words and the structural meaning of word-groups. It can be recalled that two compound words made up of lexically identical stems may be different in meaning because of the difference in the pattern of arrangement of the stems. As we saw from the corpus-based examples above not only the order but also the substitution of one of the elements in both languages may lead to semantic differences or to entirely different phraseological units.

\section{References}

Everaert, M.; E. J. van der Linden (1995) "Idioms: Structural and Psychological Perspectives".. New Jersey: Lawrence Erlbaum Associates Publishers.

Cacciari, C.; P. Tabossi (1993): "Idioms: Processing, Structure and Interpretation", New Jersey; Lawrence Erlbaum Associates Publishers.

Ginzburg, R.S./ Khiedel, S.S./Knyazeva, Sankin, A.A. (1999): English Lexicology, Moscow.

Galsworthy, J. (1970): The Fortsyte Saga I. Heinemann: London.

Galsworthy, J. (1970): The Fortsyte Saga II. Heinemann: London.

Grahame, K. (1992): The Wind In The Willows. Wordsworth Editions Limited.

Kuteli, M. (1972): "Tregime të zgjedhura", Shtëpia Botuese "Naim Frashëri", Tiranë.

Kuteli, M. (1964): Vepra Letrare 3/Novela. Tiranë: Shtëpia Botuese "Naim Frashëri".

McGraw - Hill's Dictionary of American Idioms and Phrasal Verbs, (2005). McGraw -Hill Companies, Inc. U.S.A.

McMordie, W. ; Seidl, J. (1978): "English Idioms and how to use them", Oxford University Press.

Thomai, J. (1981): "Çështje të frazeologjisë së gjuhës shqipe", Shkenca, Tiranë.

Thomai, J. (1999): "Fjalor frazeologjik i gjuhës shqipe", Shkenca, Tiranë.

Thomai, J. (1982): "Togfjalëshi, frazeologjia dhe fjala", Studime filologjike, Tiranë

Thomai, J. (1976): "Frazeologjizma foljorë në gjuhën shqipe", Studime filologjike, Tiranë.

Xoxa, Jakov (1980): Juga E Bardhë. Vëllimi I. Tiranë: Shtëpia Botuese "Naim Frashëri".

Xoxa, Jakov (1980): Juga E Bardhë. Vëllimi li. Tiranë: Shtëpia Botuese "Naim Frashëri".

Xoxa, Jakov (1980): Lulja E Kripës Së Butë. Vëllimi I. Tiranë: Shtëpia Botuese "Naim Frashëri".

Xoxa, Jakov (1981): Lulja E Kripës Së Egër. Vëllimi li. Tiranë: Shtëpia Botuese "Naim Frashëri".

Xoxa, Jakov (1965): Lumi I Vdekur. Vëllimi I. Tiranë: Shtëpia Botuese "Naim Frashëri".

Xoxa, Jakov (1971): Lumi I Vdekur. Vëllimi li. Tiranë: Shtëpia Botuese "Naim Frashëri".

Xoxa, Jakov (1971): Lumi I Vdekur. Vëllimi lii. Tiranë: Shtëpia Botuese "Naim Frashëri". 